\title{
Correspondance
}

\section{Who benefits from the embargo?}

$\mathrm{T}$ his morning [May 24] I was faced with a glaring headline in the Globe and Mail about the thousands of patients being killed by our health care institutions. The newspaper article ${ }^{1}$ discussed a study by Ross Baker and colleagues ${ }^{2}$ appearing in the May 25, 2004, issue of $C M A 7$. I immediately logged onto eCMAf to read the article, but could find neither the article nor the issue of $C M A 7$ in which it appears.

I thought there were firmly established guidelines about "advance" presentation of research results to the news media when a researcher's professional peers have not yet had a chance to read the article in question. Should the general public have access to an article, through the lay media, before the medical profession has had a chance to see it?

\section{Arnold Voth \\ Active staff \\ Royal Alexandra Hospital \\ Edmonton, Alta. \\ References \\ 1. McIlroy A, Mickleburgh R. Hospital errors kill thousands in Canada, study estimates. Globe and Mail [Toronto] 2004 May 24;Sect A:11. \\ 2. Baker GR, Norton PG, Flintoft V, Blais R, Brown A, Cox J, et al. The Canadian Adverse Events Study: the incidence of adverse events among hospital pa- tients in Canada. CMA7 2004;170(11):1678-86.}

DOI:10.1503/cmaj.1040850

A one of the many frustrated participants in the pre-release briefing for the recently published Canadian Adverse Events Study, ${ }^{1}$ I am writing to express the strongest possible objection to $C M A 7$ 's misguided policy whereby the lay media are given access to the content of medical research articles without the same privilege being extended to the stakeholders most involved. Worse, we were advised to ask the media for the material! I also seriously question the exclusion of regional health authorities and institutions from advance notification, given that they will be on the firing line when the research paper shuffles belatedly into public view.

What a mess you've created!

\section{Robert A. Burns}

Registrar

College of Physicians and Surgeons

of Alberta

Edmonton, Alta.

\section{Reference}

1. Baker GR, Norton PG, Flintoft V, Blais R, Brown A, Cox J, et al. The Canadian Adverse Events Study: the incidence of adverse events among hospital patients in Canada. CMA7 2004; 170(11):1678-86.

DOI:10.1503/cmaj.1040837

A s executive director of the Newfoundland and Labrador Health Boards Association, I wish to go on record as objecting to the CMAf process for release of the Canadian Adverse Events Study ${ }^{1}$ to the press in advance of publication.

The rationale of providing advance copies of an article only to media representatives may well be appropriate for other articles published in the journal, but it was completely unsuitable for the Canadian Adverse Events Study. This study has broad implications for all aspects of the Canadian health care system and was funded and supported by 2 federal agencies, the Canadian Institute for Health Information and the Canadian Institutes of Health Research. It would be almost tolerable if there were no access to the article for anyone before its publication in $C M A \mathcal{A}$, but it is completely unacceptable that major federal and provincial health organizations and associations, including provincial governments, are driven to approach the media as the only source for advance copies.

A far preferable method would be to hold a major national public release of the study's findings, accompanied by a press conference.

\section{John Peddle}

Executive Director

Newfoundland and Labrador Health

Boards Association

St. John's, Nfld.

\section{Reference}

1. Baker GR, Norton PG, Flintoft V, Blais R, Brown A, Cox J, et al. The Canadian Adverse Events Study: the incidence of adverse events among hospital patients in Canada. CMAJ 2004; 170(11):1678-86.

DOI:10.1503/cmaj.1040838

\section{[The editors respond:]}

Tn our view, the most important Istakeholder" in Canadian hospitals and Canadian health care research is the Canadian public. And it is in the public's interest that accredited journalists are sent advance notice of material published in CMAJ. This material is embargoed until 17h EST the evening before our publication date, at which time the issue becomes available online.

The purpose of the embargo is to give journalists time to reflect on the material and seek expert reaction before reporting to the general public, and to avoid giving preferential treatment to any one news source.

It is regrettable that, in the case of the Canadian Adverse Events Study, the Edmonton Fournal and some other members of the CanWest group reported on the study results before the embargo expired. CanWest informed us that the Edmonton fournal obtained a leaked copy and did not feel bound by the embargo, which strikes us as a demonstration of the merits of our current policy of a controlled release to the press.

Anyone approached by a journalist to comment on material published in CMAJ is free to ask the reporter for an embargoed copy before offering a response. This is common journalistic practice. We have no wish to orchestrate the reception of scientific findings or health news by experts, government, professional associations or any other "stakeholders." Spin doctoring is not our business.

\section{Anne Marie Todkill \\ John Hoey \\ CMA7}

DOI:10.1503/cmaj.1040947 